\title{
Characteristics of Macroalgal Consumption by Eight Herbivorous Coral Reef Fishes From the Xisha Islands, China, as Determined by Microscopy, 18S rRNA High-throughput Sequencing and Stable Isotope Analyses
}

\section{Peng Wu}

South China Sea Fisheries Research Institute https://orcid.org/0000-0003-1703-4795

\section{Teng Wang}

South China Sea Fisheries Research Institute

Yong Liu ( $\sim$ liuyong@scsfri.ac.cn )

South China Sea Fisheries Research Institute

Chunhou Li

South China Sea Fisheries Research Institute

Yayuan Xiao

South China Sea Fisheries Research Institute

Shannan Xu

South China Sea Fisheries Research Institute

Tingting Han

South China Sea Fisheries Research Institute

Lin Lin

South China Sea Fisheries Research Institute

Qiumei Quan

South China Sea Fisheries Research Institute

\section{Research Article}

Keywords: coral reefs, herbivorous fishes, macroalgal species composition, dietary spectrum, intestinal contents

Posted Date: September 21st, 2021

DOl: https://doi.org/10.21203/rs.3.rs-892727/v1 
License: (c) (i) This work is licensed under a Creative Commons Attribution 4.0 International License. Read Full License 


\section{Abstract}

Herbivorous fishes play an important role in controlling the overabundance of macroalgae on coral reefs. Understanding the feeding selectivity and consumption of macroalgae by herbivorous fishes can be challenging in studies of their ecological role in the preservation and recovery of coral reefs. Coral reef decline, macroalgal overgrowth and overfishing are clearly visible in the Xisha Islands, China. However, there have been no studies of the feeding behaviors of herbivorous fishes in this area. We used microscopy, 18S rRNA high-throughput sequencing and stable isotope analyses to comprehensively examine the dietary spectrum of eight herbivorous reef fish species common in the Xisha Islands, including one parrotfish, two chub, two unicorn fish and three rabbitfish. Multi-technique analyses of intestinal contents revealed that Kyphosus vaigiensis, Naso unicornis and Siganus argenteus showed a high consumption potential of macroalgae, suggesting that they are the key browsers which should receive priority protection in in the Xisha Islands. Kyphosus cinerascens, $K$. vaigiensis, $N$. unicornis and $S$. punctatissimus fed on the entire macroalgal thallus, indicating their greater ecological importance compared with species which only consume the algal fronds. However, Calotomus carolinus can consume the red alga Pneophyllum conicum, which is widely distributed on Indo-Pacific coral reefs and can overgrow and kill live corals. Clearly, a diverse herbivorous fish fauna is very important in the Xisha coral reefs. These results not only demonstrated the various functions of different herbivorous fish species in macroalgal removal, but also provided insights into the management of herbivorous fishes on the coral reefs of the South China Sea.

\section{Introduction}

Coral reefs are often called the tropical rainforests of the ocean and are the most productive and biologically diverse ecosystem in the world, supporting more than $25 \%$ of all known marine species (Moberg and Folke 1999; Walker and Wood, 2005). However, the world's coral reefs are in serious decline due to numerous anthropogenic activities and global climate disturbances (Wilkinson, 2008; Liu et al. 2021). Nineteen percent of the world's coral reefs were lost in the 4 years of $2004-2008$, and only $46 \%$ of the world's reefs were considered to be in a relatively healthy condition during that period (Wilkinson, 2008). The decline of coral reefs can involve a shift from coral towards macroalgae as the dominant feature (Cheal et al. 2010; Kopp et al. 2010). The majority of China's coral reefs occur around the Xisha Islands in the Indo-Pacific region and have suffered recent dramatic declines in coral cover (Li et al. 2018). Many parts of the Xisha Islands' reefs are now dominated by macroalgal growths (Chen et al. 2019). A predominance of macroalgae hinders the settlement, survival and growth of corals, so that a healthy coral reef ecosystem is very difficult to reestablish (Puk et al. 2016; Dell et al. 2020). Phase shifts in the balance of coral/macroalgal species have been anecdotally attributed insufficient herbivore activity, eutrophication, environmental disturbances (e.g. typhoons, ocean warming and coral bleaching, etc.), bottom-up factors (nutrients pollution) or a combination of these factors (Cheal et al. 2010; Russ et al. 2015; Neilson et al. 2018; Bruno et al. 2019; Adam et al. 2021). 
Herbivorous reef fishes are the major consumers of macroalgae on coral reefs (Cheal et al. 2010). Parrotfish (Scarus and Sparisoma spp.), chub (Kyphosus spp.), unicorn fish (Naso spp.) and rabbitfish (Siganus spp.) are recognized as the important macroalgal grazers on coral reefs (Lefevre and Bellwood, 2011; Puk et al. 2016; Dell et al. 2020). The feeding preferences of herbivorous reef fishes differ at the species level (Hoey and Bellwood, 2009; Duran et al. 2019; Dell et al. 2020). Parrotfish appear to prefer green and red algae, but some taxa (e.g., Naso spp. and Kyphosus spp.) generally target brown macroalgae (Puk et al. 2016). Of the over 50 herbivorous fish species identified off Lizard Island, northern Great Barrier Reef, only one, Naso unicornis, fed on the erect brown macroalga Sargassum across all habitats (Hoey and Bellwood, 2009). A study of the feeding behaviors of four rabbitfish species, indicated that Siganus argenteus and S. sutorwere generalist herbivores, foraging on turf algae, macroalgae, seagrass and epiphytic algae, while $S$. corallinus and $S$. stellatus were specialist herbivores foraging primarily on turf algae growing on the reef substrate (Ebrahim et al. 2020). Herbivore species richness appears to be critical in generally lowering macroalgal abundance because of the complementary feeding habits of a diverse assemblage of herbivores (Burkepile and Hay, 2008). Therefore, it is essential to understand the dietary spectra of the various herbivorous reef fishes to understand their cumulative effect on coral reef health. However, very little is currently known about the macroalgal feeding preferences of the herbivorous reef fishes on the coral reefs off the Xisha Islands, and this limits our understanding of their different functional roles in controlling the spread of macroalgae.

The feeding ecology of herbivorous fishes on coral reefs is usually determined by behavioral observations, counting the number of bites taken by fish feeding in the field (Mantyka and Bellwood, 2007; Dell et al. 2020; Ebrahim et al. 2020), or by microscopic examination of intestinal contents (Dromard et al. 2015). These methods are convenient and provide detailed information on the dietary spectrum of different species (de Carvalho et al. 2019). However, there are some practical problems; small, fragile, or morphologically indistinct organisms are difficult to identify in intestinal samples, especially after digestion (Dromard et al. 2015; Kume et al. 2021). Stable isotope analysis is a powerful tool which can reveal feeding behavior over an extended period, although with some taxonomic limitations (Rodriguez-Barreras et al. 2020; Kume et al. 2021). High-throughput sequencing is emerging as a molecular method to estimate fish dietary composition by identifying the taxa eaten from genomic DNA recovered from fish intestines (Corse et al. 2010; Leray et al. 2015). It is more effective when used in conjunction with reference sequence databases such as GenBank (Devloo-Delva et al. 2019). Using a combination of these three methods allows comprehensive descriptions of the dietary composition of various fish species.

Coral cover off the Xisha Islands has declined dramatically over the past 15 years (Li et al. 2018) and macroalgae have become dominant in many of their coral reef areas (Chen et al. 2019). Furthermore, overfishing has become a serious threat for these reefs (Zhao et al. 2016). We explored the dietary differences of eight different herbivorous reef fishes common around the Xisha Islands, based on microscopic examination, 18S rRNA high-throughput sequencing and stable isotope analyses. We focused on comparisons of the macroalgal feeding selectivity of herbivores, including one parrotfish 
(Calotomus carolinus - CC), two chub (Kyphosus cinerascens - KC, and K. vaigiensis - KV), two unicorn fish (Naso brevirostris - NB, and N. unicornis - NU) and three rabbitfish (Siganus argenteus -

SA, S. puellus - Spe, and S. punctatissimus - SPn). The results provided key information on the ecological function of these herbivorous fishes in removing macroalgae from coral reefs, and gave insights into the most effective overfishing prevention measures to keep the coral reef ecosystem at its most healthy.

\section{Materials And Methods}

\section{Study site and fish sample collection}

The Xisha Islands, in the central South China Sea, are derived from coral reefs and comprise over 40 islands, reefs and cays, including the Dongdao Atolls, the Huaguang Atolls, the Xuande Atolls, the Yongle Atolls, and some smaller islands (Zhao et al. 2017; Ding et al. 2019; Zhao et al. 2019). The Qilianyu Islets and Cays (16 $\left.59^{\prime} \mathrm{N}, 112^{\circ} 18^{\prime} \mathrm{E}\right)$ of the Xisha Islands comprise an arced reef flat, which extends in a NW-SE direction and curves to the NNE (Shen et al. 2017). Over 100 fish species have been recorded off the Qilianyu Islets and Cays, with the dominant species belonging to the families Pomacentridae, Labridae and Scaridae (Li et al. 2017). Eight herbivorous reef fish species common in the Qilianyu Islets and Cays were collected by SCUBA in June 2020. The details of the fishes sampled in this study, along with their phylogenetic classification and feeding strategies, are shown in Table 1. The feeding strategy of each species was determined based on the previous studies. All of the fishes collected were kept at $-4^{\circ} \mathrm{C}$ and transported to the laboratory, where they were dissected using sterile scissors. The anterior intestinal contents were separated and divided into two subsamples. One subsample was used for microscopic examination, and the another was used for 18S rRNA high-throughput sequencing analysis. A small piece of muscle tissue was sampled from each fish and used for stable isotope analysis.

\section{Intestinal contents for microscopical analysis examination}

Intestinal contents of each fish species were collected for dietary assessment. Photographs of the food items were taken using a microscope (Zeiss SteREO Discovery.V20, Germany). Macrophytes (Macroalgae and seagrasses) were identified according to their morphological traits (Titlyanov et al. 2017; Huang, 2018).

\section{Composition of intestinal contents measured by $18 \mathrm{~S}$ rRNA high-throughput sequencing analysis}

The total DNA of intestinal contents ( $0.2 \mathrm{~g}$ sample) of individual fish was extracted using a QIAamp ${ }^{\circledR}$ Fast DNA Stool Mini Kit (Qiagen, Germantown, MD, USA) according to the manufacturer's protocols. The total DNA recovered from each fish species was pooled for PCR amplification which targeted the V4 region of the eukaryotic $18 \mathrm{~S}$ rRNA gene using primers 528F (5'-GCGGTAATTCCAGCTCCAA-3') and 706R (5'-AATCCRAGAATTTCACCTCT-3'), where the barcodes were an eight-base sequence unique to each sample (Cheung et al. 2010). Amplicons were extracted from $2 \%$ agarose gels and purified using the AMPure XP Beads (Beckman, Agencourt, USA). These purified amplicons were pooled in equimolar 
paired-end sequences $(2 \times 250)$ on an Illumina platform (Gene Denovo Co., Guangzhou, China). Raw reads for each fish species were deposited into the NCBI Sequence Read Archive (SRA) database with the accession number PRJNA742779. The representative sequences affiliated to the phyla Chlorophyta, Ochrophyta and Rhodophyta obtained in this study were deposited in the GenBank database under accession numbers MZ481947-MZ481964, MZ481932-MZ481946 and MZ481965-MZ482014, respectively.

Raw reads were filtered using FASTP (V0.18.0) to obtain high quality clean reads according to the following rules: (1) remove reads containing more than $10 \%$ of unknown nucleotides and (2) remove reads containing less than $50 \%$ of bases with a quality (Q-value) $\varangle 20$ (Chen et al. 2018). Paired-end clean reads were merged as raw tags using FLSAH (V1.2.11) with a minimum overlap of $10 \mathrm{bp}$ and mismatch error rates of $2 \%$ or less (Magoc and Salzberg, 2011). Noisy sequences of raw tags were then filtered using QIIME (V1.9.1) (Caporaso et al. 2010) under specific filtering conditions (Bokulich et al., 2013) to obtain high quality clean tags. Clean tags were searched against the reference database (http://drive5.com/uchime/uchime_download.html) to perform reference-based chimera checks, using the UCHIME algorithm (Edgar et al. 2011). All chimeric tags were removed to finally obtain effective tags for further analysis.

The effective tags were clustered into operational taxonomic units (OTUs) of $\geq 97 \%$ similarity using UPARSE (V9.2.64) (Edgar, 2013). A dominant sequence was selected within each cluster as a representative sequence. The representative sequences were then picked-out to annotate taxonomic assignments using the RDP classifier (V2.2) (Wang et al. 2007) based on the SILVA database (V132) (Pruesse et al. 2007). The OTU sequences belonging to class Actinopteri were discarded in further analysis. Moreover, if an OTU sequence could not be assigned to any phylum in the SILVA database, it was subjected to a further BLAST search (http://blast.ncbi.nlm.nih.gov/Blast.cgi). The taxonomic classification was then finally confirmed by its similarity to a BLAST result.

\section{Stable isotope analysis}

Fish muscle tissues were dried at $60^{\circ} \mathrm{C}$ to a constant weight. Samples were then ground to a fine, homogeneous powder using an automatic sample grinder (Jxfstprp-24, Jingxin Co., Shanghai, China). Samples were taken for carbon and nitrogen stable isotope analysis using a continuous-flow isotope ratio mass spectrometer (Finnigan MAT 253, Thermo Scientific, USA) coupled to an elemental analyzer (Flash EA 1112, Thermo Scientific, USA). The $\mathrm{C}$ and $\mathrm{N}$ isotope ratios were determined as $\delta^{13} \mathrm{C}$ and $\delta^{15} \mathrm{~N}$, respectively, according to the following formula:

$$
\delta^{13} \mathrm{C} \text { or } \delta^{15} \mathrm{~N}(\%)=\left(\frac{\mathrm{R}_{\text {sample }}}{\mathrm{R}_{\text {standard }}}-1\right) \times 1000,
$$

where $\mathrm{R}$ is the corresponding ratio ${ }^{13} \mathrm{C} /{ }^{12} \mathrm{C}$ or ${ }^{15} \mathrm{~N} /{ }^{14} \mathrm{~N}, \mathrm{R}_{\text {sample }}$ is measured for fish, and $\mathrm{R}_{\text {standard }}$ is an international standard (Pee Dee Belemnite for $\mathrm{C}$ isotopes and atmospheric $\mathrm{N}_{2}$ for $\mathrm{N}$ isotopes). 


\section{Data analysis}

Bar charts of the community composition and stable isotope signatures $\left(\delta^{13} \mathrm{C}\right.$ and $\left.\delta^{15} \mathrm{~N}\right)$ of fish muscles were constructed using Origin 2018 software (OriginLab Co., Northampton, MA, USA). A phylogenetic tree of $18 \mathrm{~S}$ rRNA sequences related to the phyla Chlorophyta, Ochrophyta and Rhodophyta was constructed using MEGA $X$ and the neighbor-joining algorithm, and the maximum composite likelihood method with bootstrap analyses for 1,000 replicates (Kumar et al. 2018). A heat map of the relative abundance of the 18S rRNA sequences belonging to the phyla Chlorophyta, Ochrophyta and Rhodophyta was individually generated using the OmicShare tools (http://www.omicshare.com/tools). Dominant OTUs from the heat maps were selected to analyze taxonomic assignments using BLAST research.

\section{Results}

\section{Microscopic observations of fish intestinal contents}

Intestinal contents of the eight fish species collected were analyzed according to microscopic observations. After thorough washing, anterior intestinal contents of fishes were examined and a high proportion of flocculent detritus was found. Coral sand was only detected in the intestinal contents of CC and SA (data not shown). Importantly, macrophytes (macroalgae or seagrasses) were easily observed in fish intestines (Table 2). The number of macrophyte species consumed by the eight herbivorous reef fishes varied. SA consumed the highest number of macrophyte species (six species), followed by $\mathrm{NU}$ (four species). However, only a few macrophyte species could be identified according to their morphological traits, while other fragments belonging to Chlorophyta, Ochrophyta or Rhodophyta were too small and were difficult to identify. The green algae Valonia ventricosa and Halimeda sp. were detected in the fish intestines of NU and SA, respectively. The brown alga Turbinaria ornata and the red alga Acanthophora spp. were observed in the intestinal contents of NU and SPn, respectively. In addition, the seagrass Halophila ovalis was identified as a food source of SA.

\section{Molecular detection of macrophyte species composition in fish intestines}

The dietary spectra of the eight fishes were analyzed with 18S rRNA gene high-throughput sequencing at the phylum and class levels (Fig. 1). The 15 most abundant phyla accounted for $88.2 \%-99.3 \%$ of the total sequences found in the eight fish species' intestines (Fig. 1a). There were marked differences in the relative abundance of the dominant phyla in each species sample. Porifera was the most abundant taxon in $\mathrm{CC}$, which was further identified as Demospongiae (sponges) (Fig. 1). The dominant phyla in KC were Bacillariophyta and Porifera. Ochrophyta, Streptophyta and Bigyra were significantly more abundant in $\mathrm{KV}, \mathrm{SA}$ and SPn, respectively. However, Cnidaria, mainly Anthozoa (corals), were much higher in $\mathrm{SPe}, \mathrm{NB}$, $\mathrm{NU}$ and CC (Fig. 1). Sequences belonging to Streptophyta were identified as Halophila ovalis, a seagrass species which occurred in the intestines of CC, NB, SA and SPn.

Sequences referring to the phyla Chlorophyta, Ochrophyta and Rhodophyta found in the eight fishes were further analyzed (Fig. 2). A total of 18, 15 and 47 OTUs were observed belonging to Chlorophyta, 
Ochrophyta and Rhodophyta, respectively (Fig. 2a). A phylogenetic tree of the observed OTUs was constructed and is shown in Fig. 3. Chlorophyta OTUs were most diverse in KV and SA ( $\geq 10$ OTUs). The highest numbers of Rhodophyta OTUs (23 OTUs) were observed in KC and KV. Ochrophyta OTUs were most abundant in KV (11 OTUs). The relative abundance of consumed macroalgae found in fish intestines are shown in Fig. 2b. KV consumed the greatest abundance of macroalgae (76.9\%), followed by KC (14.5\%). NU preferred to take brown algae, while SPn consumed more green algae. The diet of SA contained $2.9 \%$ green algae, $0.8 \%$ brown algae and $1.9 \%$ red algae.

The differences in the macroalgal composition between the intestinal contents of the eight fish species were analyzed (Fig. 4 and Table 3). The species composition of green algae or red algae in the eight herbivorous fishes diets was quite different (Fig. 4a and c). Regarding the green algae, Otu000030, identified as Dictyosphaeria cavernosa, was abundant in KV. Otu000055, which was very similar to Ulvella leptochaete, was a dominant component in SA and KC. Both Otu000067 and Otu000102 were affiliated to the genus Cladophora. The occurrence of Otu000067 was higher in KC, while Otu000102 dominated in NB and SA. Regarding the red algae (Fig. 4C), Otu000056 dominated in SA and showed a high similarity to Spyridia filamentosa. Otu000077 was related to Centroceras hyalacanthum, and was a major component in SA and SPn. Otu000094 matched with Ceramium sinicola and was relatively abundant in KC. Otu000200 and Otu000260 were relatively abundant in KV and were similar to Peyssonnelia rumoiana and Peyssonnelia armorica, respectively. Otu000535 was identified as the red alga Peyssonnelia rosenvingei and was very abundant in CC. The intestinal contents of CC also contained a dominant OTU (Otu000554), which was matched with Pneophyllum conicum. The dominant OTUs in NU included Otu000309 and Otu000874, which were similar to Chondrophycus cf. undulates and Ceramium sinicola, respectively. Regarding the brown algae (Fig. 4b), Otu000009, related to Lobophora variegate, was dominant in the intestinal contents of all the fishes, except SA. Otu000014 was also abundant in most fishes, especially SA in which it was most abundant.

\section{Stable isotope analysis}

Stable isotope values of $\delta^{13} \mathrm{C}$ and $\delta^{15} \mathrm{~N}$ from the eight herbivorous fish species are shown as a biplot (Fig. 5). The $\delta^{13} \mathrm{C}$ values across species ranged from -19.2 to $-12.3 \%$, and were more enriched in CC $(-12.3 \pm 0.8 \%$ o), NU $(-13.4 \pm 2.6 \%$ o $)$ and KV $(-13.8 \pm 1.5 \%$ o). However, SPn and NB had lower enrichment of $\delta^{13} \mathrm{C}$ values, with $-19.2 \pm 0.9 \%$ ond $-18.0 \pm .02 \%$, respectively. The $\delta^{15} \mathrm{~N}$ values of fishes varied from 5.1 to $8.3 \%$ o. KV $\left(8.3 \pm 0.5 \%\right.$ o) had much higher $\delta^{15} \mathrm{~N}$ values, while $\mathrm{NU}$ showed the lowest $\delta^{15} \mathrm{~N}$ values $\left(5.1 \pm 0.6 \%\right.$ o). KC, SPe and SA had generally similar $\delta^{13} \mathrm{C}$ and $\delta^{15} \mathrm{~N}$ values. The differences in $\delta^{15} \mathrm{~N}$ observed in the eight fishes indicated that NU occupied a relatively low trophic position.

\section{Discussion}

\section{Microscopic examination and high-throughput sequencing analyses of fish intestinal contents}


Microscopic examination and 18S rRNA high-throughput sequencing analyses were used to investigate the dietary composition of eight herbivorous reef fish species off the Xisha Islands, China. There were some similarities in the results of the two methods. The seagrass Halophila ovalis was observed in the intestinal contents of SA based on microscopic examination (Table 2), and high-throughput sequencing analysis found that this seagrass (Liliopsida) also dominated the intestinal contents of SA (Fig. 1b). Microscopic examination revealed coral sand in the intestinal contents of CC and SA (data not shown). High-throughput sequencing analysis also showed a high abundance of the class Anthozoa (corals) (Fig. 1b).

However, 18S rRNA high-throughput sequencing analysis provided higher taxonomic resolution of dietary composition, compared with microscopic examination. For example, some taxa which were found to dominate the intestinal contents using molecular analysis, such as Porifera, Cnidaria, Bacillariophyta, etc. (Fig. 1a) were not detected by microscopic examination. The possible reasons were as follows. First, small organisms or digested organisms are too difficult to identify using a microscope (Dromard et al. 2015; Kume et al. 2021). In this study, microscopic examination found a large amount of detritus in the fish intestinal contents (data not shown). Dromard et al. (2015) also observed a very large proportion of unidentified detritus in the intestines of Scaridae using a microscope. Second, high-throughput sequencing is highly sensitive and can detect traces of DNA in mixed samples. This molecular technique can discriminate OTUs even with only a single nucleotide variation within the targeted amplified region (Albaina et al. 2016). Third, the number of sampled fishes in this study was small and some taxa were not observed using the microscope. For example, previous studies have shown that SPe can consume sponges (Hoey et al. 2013). While microscopic examination did not find any sponge remains in fish intestinal contents, Demospongiae (sponges) were identified as the main food for SPe using highthroughput sequencing (Fig. 1b). Leray et al. (2015) also showed that pyrosequencing analysis could broaden the recognition of the food webs of coral dwelling predatory fish and achieved unprecedented taxonomic resolution of their diets. The complimentary use of molecular analysis enabled our study to reveal the highly complex dietary spectrum of the herbivorous reef fishes, which we studied, an impossible result if we had relied on microscopic examination alone.

\section{Differences in macroalgal consumption among herbivorous coral reef fishes}

Both microscopic examination and high-throughput sequencing analyses of intestinal contents showed that the eight herbivorous reef fishes studied fed on macroalgae. However, the estimates of their consumption potential of macroalgae differed according to the results of the two methods. Based on microscopic examination, we found that SA fed on the most species of macroalgae (five species), followed by NU (four species) (Table 2). However, according to the high-throughput sequencing results, $\mathrm{KV}$ removed the highest diversity of macroalgae species as well as the greatest quantity of macroalgae, followed by KC, SA and NU (Fig. 2). In addition, NU was found to occupy the lowest trophic position (Fig. 5). Accordingly, we clearly demonstrated that KV, NU and SA showed a high consumption potential of macroalgae from the coral reef. Similarly, previous studies have also shown that $\mathrm{KV}$ and $\mathrm{NU}$ were highly effective in consuming macroalgae, especially the brown macroalgae 
(Lefevre and Bellwood, 2011; Streit et al. 2015; Puk et al. 2016). In the Great Barrier Reef, Australia, SA has been shown to remove a range of substrate algae, including turf algae, macroalgae, seagrass and epiphytic algae (Ebrahim et al. 2020). Furthermore, SA have been shown to especially focus more on red and green macroalgae (Hoey et al. 2013). Similarly, we found that KV and NU were highly effective consumers of brown macroalgae, while SA favored red and green macroalgae. Of course, macroalgal grazing selectivity of herbivorous fishes can vary with location, season, food availability and according to the other fish species present (Puk et al. 2016).

\section{Ecological function of herbivorous fishes in removing macroalgae from coral reefs}

In addition to identifying the diets of the eight herbivorous reef fishes studied, our results demonstrated the ecological importance of these fishes in removing macroalgae from coral reefs. Herbivorous fishes are broadly classified into four functional groups: excavators, scrapers, grazers, and browsers (Hoey and Bellwood, 2009). Excavators, scrapers and grazers generally consume small macroalgae and algal turfs, while browsers target large, erect macroalgal species and play a critical part in controlling macroalgal spreading (Hoey and Bellwood, 2009; Michael et al. 2013; Ebrahim et al. 2020). Previous studies have shown that CC, KC, KV, NB, NU and SA belong to the browser group (Puk et al. 2016; Sura et al. 2021) and this was confirmed in our study. Based on microscopic examination, NU can consume $V$. ventricosa and T. ornate, while SA can consume Halimeda sp. (Table 2). According to the 18S rRNA high-throughput sequencing analysis, we found that $\mathrm{CC}, \mathrm{KC}, \mathrm{KV}, \mathrm{NB}$ and $\mathrm{NU}$ consumed the brown alga Lobophora variegate, and that $\mathrm{KV}$ and $\mathrm{NU}$ foraged especially heavily on this macroalgae. However, SA fed more on Dictyota linearis (Fig. 2 and Table 3). KV played an important role in removing the green alga Dictyosphaeria cavernosa, while SA preferred to feed on the red algae Spyridia filamentosa and Centroceras hyalacanthum. KV also preferred to consume Peyssonnelia spp. (Fig. 2 and Table 3). The macroalgae mentioned above all belonged to either the upright calcareous or fleshy macroalgae. These two macroalgae groups are problematic as they probably inhibit coral settlement, while the crustose calcareous algae and algal turfs have only minor effects on coral settlement (DiazPulido et al. 2010). Overgrowth of Lobophora and Dictyota is widely supposed to reduce coral settlement (Foster et al. 2008; Diaz-Pulido et al. 2010; Evensen et al. 2019; Vieira, 2020) and the spread of Dictyota can even cause coral disease outbreaks (Brandt et al. 2012). Unfortunately, Lobophora and Dictyota, are the dominant species on Indo-Pacific coral reefs (Cardoso et al. 2009; Titlyanov et al. 2017). We found that the nitrogen signature $\left(\delta^{15} \mathrm{~N}\right)$ of $\mathrm{NU}$ was lower than that of the other herbivorous fishes (Fig. 5), indicating a high consumption potential of macroalgae. In general, we suggested that KV, NU and SA were the key browsers removing macroalgae from reefs off the Xisha Islands. This result is similar to that of a previous view, which recommended that KV, NU. and Siganus canaliculatus were the predominant removers of macroalgae, the "true macroalgae browsers" of coral reefs (Puk et al. 2016).

Herbivorous fishes which eat the entire macroalgal thallus have a more important functional impact on macroalgae removal from coral reefs than species which only consume algal fronds (Streit et al. 2015). In this study, KC, KV, NU and SPn were found to feed on the entire macroalgal thallus (Table 2). Streit et al. (2015) also showed that KV and NU consumed the entire macroalgal thallus in approximately 
$90 \%$ of bites taken. Body size, tooth shape, and feeding behavior of different herbivores may result in these functional differences. SP was found to feed on Acanthophora sp. (Table 2) which can inhibit the successful settlement of coral planulae (Vermeij et al. 2009). The red alga, Pneophyllum conicum is widely distributed on Indo-Pacific coral reefs and can overgrow and kill live corals (Antonius, 2001). Coincidentally, we found that CC consumed P. conicum (Table 3). In addition, herbivorous fishes can selectively remove some macroalgae, which often occur in the Xisha Islands, including Ulvella, Cladophora, Sphacelaria, Spyridia, Centroceras, Ceramium and Neosiphonia (Table 3). The spread of macroalgae can negatively affect coral reefs through the inhibition of coral fecundity and growth, the reduction of coral larval settlement and recruitment and the increasing prevalence of coral diseases (Dell et al. 2020). Burkepile and Hay (2008) identified herbivore species richness and feeding complementarity as key factors in the effective suppression of the spread of macroalgae in a coral ecosystem. In summary we recommend an end to overfishing, in particular of key browser species, such as KV, NU and SA, in order to control the spread of macroalgae on the reefs off the Xisha Islands. The preservation of as great a diversity of herbivorous fishes on coral reefs will serve to better protect and reestablish beleaguered coral reefs.

\section{Declarations}

\section{Acknowledgments}

We thank International Science Editing (http://www.internationalscienceediting.com) for editing this manuscript.

\section{Author Contributions}

Conceptualization, PW, YL and CH L; investigation, PW, TW, YY X, TT H and QM Q; methodology, PW, TW and TT H; formal analysis, PW and QM Q; writing original draft, $\mathrm{PW}$ and $\mathrm{YY} X$; writing-review \& editing, PW, $\mathrm{LL}, \mathrm{YL}, \mathrm{CH} \mathrm{L}$ SN $\mathrm{X}$ and TW; data curation, $\mathrm{YL}$ and $\mathrm{LL}$; funding acquisition, $\mathrm{CH} \mathrm{L}$ and $\mathrm{PW}$.

\section{Funding}

This research was supported by the National Key R\&D Program of China (2018YFD0900803), Key Special Project for Introduced Talents Team of Southern Marine Science and Engineering Guangdong Laboratory (Guangzhou) (GML2019ZD0605), Central Public-interest Scientific Institution Basal Research Fund, South China Sea Fisheries Research Institute, CAFS (No. 2019TS28, No. 2021SD04), Financial Fund of the Ministry of Agriculture and Rural Affairs, P. R. of China (NFZX2018), Central Public-interest Scientific Institution Basal Research Fund, CAFS (No. 2020TD16), Science and Technology Planning Project of Guangdong Province (2019B121201001) and Fundamental and Applied Fundamental Research Major Program of Guangdong Province (2019B030302004-05).

\section{Conflicts of Interest}

The authors declare no conflict of interest. 


\section{Ethical approval}

All work undertaken in this study complied with committee on Laboratory Animal Welfare and Ethics of

South China Sea Fisheries Research Institute, Chinese Academy of Fishery Sciences.

\section{References}

Adam TC, Burkepile DE, Holbrook SJ, Carpenter RC, Claudet J, Loiseau C, Thiault L, Brooks AJ, Washburn L, Schmitt RJ (2021) Landscape-scale patterns of nutrient enrichment in a coral reef ecosystem: implications for coral to algae phase shifts. Ecol Appl, 31(1):2227

Albaina A, Aguirre M, Abad D, Santos M, Estonba A (2016) 18S rRNA V9 metabarcoding for diet characterization: a critical evaluation with two sympatric zooplanktivorous fish species. Ecol Evol 6:18091824

Antonius A (2001) Pneophyllum conicum, a coralline red alga causing coral reef-death in Mauritius. Coral Reefs 19:418-418

Bellwood S, Bellwood DR (2011) Latitudinal variation in macroalgal consumption by fishes on the Great Barrier Reef. Mar Ecol Prog Ser 426:241-252

Bokulich NA, Subramanian S, Faith JJ, Gevers D, Gordon JI, Knight R, Mills DA, Caporaso JG (2013) Quality-filtering vastly improves diversity estimates from Illumina amplicon sequencing. Nat Methods 10:57-59

Brandt ME, Ruttenberg BI, Waara R, Miller J, Witcher B, Estep AJ, Patterson M (2012) Dynamics of an acute coral disease outbreak associated with the macroalgae Dictyota spp. in dry Tortugas National Park, Florida, USA. B Mar Sci 88:1035-1050

Bruno JF, Cote IM, Toth LT (2019) Climate change, coral loss, and the curious case of the Parrotfish paradigm: Why don't marine protected areas improve reef resilience? Ann Rev Mar Sci, 11:307-334

Burkepile DE, Hay ME (2008) Herbivore species richness and feeding complementarity affect community structure and function on a coral reef. P Natl Acad Sci USA 105:16201-16206

Caporaso JG, Kuczynski J, Stombaugh J, Bittinger K, Bushman FD, Costello EK, Fierer N, Pena AG, Goodrich JK, Gordon JI, Huttley GA, Kelley ST, Knights D, Koenig JE, Ley RE, Lozupone CA, McDonald D, Muegge BD, Pirrung M, Reeder J, Sevinsky JR, Tumbaugh PJ, Walters WA, Widmann J, Yatsunenko T, Zaneveld J, Knight R (2010) QIIME allows analysis of high-throughput community sequencing data. Nat Methods 7:335-336

Cardoso SC, Soares MC, Oxenford HA, Côté IM (2009) Interspecific differences in foraging behaviour and functional role of Caribbean parrotfish. Marine Biodiversity Records 2:148 
Cheal AJ, MacNeil MA, Cripps E, Emslie MJ, Jonker M, Schaffelke B, Sweatman H (2010) Coralmacroalgal phase shifts or reef resilience: links with diversity and functional roles of herbivorous fishes on the Great Barrier Reef. Coral Reefs 29:1005-1015

Chen S, Zhou Y, Chen Y, Gu J (2018) Fastp: an ultra-fast all-in-one FASTQ preprocessor. Bioinformatics 34:884-890

Chen XY, Yu KF, Huang XY, Wang YH, Liao ZH, Zhang RJ, Yao QC, Wang JK, Wang WH, Tao SC, Zhang HL (2019) Atmospheric nitrogen deposition increases the possibility of macroalgal dominance on remote coral reefs. J Geophys Res-Biogeo 124:1355-1369

Cheung MK, Au CH, Chu KH, Kwan HS, Wong CK (2010) Composition and genetic diversity of picoeukaryotes in subtropical coastal waters as revealed by 454 pyrosequencing. ISME J 4:1053-1059

Choat JH, Robbins WD, Clements KD (2004) The trophic status of herbivorous fishes on coral reefs. Mar Biol 145:445-454

Corse E, Costedoat C, Chappaz R, Pech N, Martin JF, Gilles A (2010) A PCR-based method for diet analysis in freshwater organisms using 18S rDNA barcoding on faeces. Mol Ecol Resour 10:96-108

Cvitanovic C, Bellwood DR (2009) Local variation in herbivore feeding activity on an inshore reef of the Great Barrier Reef. Coral Reefs 28: 127-133

de Carvalho DR, de Castro DMP, Callisto M, Chaves AJD, Moreira MZ, Pompeu PS (2019) Stable isotopes and stomach content analyses indicate omnivorous habits and opportunistic feeding behavior of an invasive fish. Aquat Ecol 53:365-381

Dell CLA, Longo GO, Burkepile DE, Manfrino C (2020) Few herbivore species consume dominant macroalgae on a Caribbean Coral Reef. Front Mar Sci 7:676

Devloo-Delva F, Huerlimann R, Chua G, Matley JK, Heupel MR, Simpfendorfer CA, Maes GE. (2019) How does marker choice affect your diet analysis: comparing genetic markers and digestion levels for diet metabarcoding of tropical-reef piscivores. Mar Freshwater Res 70:8-18

Diaz-Pulido G, Harii S, McCook LJ, Hoegh-Guldberg O (2010) The impact of benthic algae on the settlement of a reef-building coral. Coral Reefs 29:203-208

Ding JF, Jiang FH, Li JX, Wang ZX, Sun CJ, Wang ZY, Fu L, Ding NX, He CF (2019) Microplastics in the coral reef systems from Xisha Islands of South China Sea. Environ Sci Technol 53:8036-8046

Dromard CR, Bouchon-Navaro Y, Harmelin-Vivien M, Bouchon C (2015) Diversity of trophic niches among herbivorous fishes on a Caribbean reef (Guadeloupe, Lesser Antilles), evidenced by stable isotope and gut content analyses. J Sea Res 95:124-131 
Duran A, Adam TC, Palma L, Moreno S, Collado-Vides L, Burkepile DE (2019) Feeding behavior in Caribbean surgeonfishes varies across fish size, algal abundance, and habitat characteristics. Mar Ecol 00:12561

Ebrahim A, Martin TSH, Mumby PJ, Olds AD, Tibbetts IR (2020) Differences in diet and foraging behaviour of commercially important rabbitfish species on coral reefs in the Indian Ocean. Coral Reefs 39:977-988

Edgar RC (2013) UPARSE: highly accurate OTU sequences from microbial amplicon reads. Nat Methods 10:996-998

Edgar RC, Haas BJ, Clemente JC, Quince C, Knight R (2011) UCHIME improves sensitivity and speed of chimera detection. Bioinformatics 27:2194-2200

Evensen NR, Doropoulos C, Wong KJ, Mumby PJ (2019) Stage-specific effects of Lobophora on the recruitment success of a reef-building coral. Coral Reefs 38:489-498

Foster NL, Box SJ, Mumby PJ (2008) Competitive effects of macroalgae on the fecundity of the reefbuilding coral Montastraea annularis. Mar Ecol Prog Ser 367:143-152

Hoey AS, Bellwood DR (2009) Limited functional redundancy in a high diversity system: single species dominates key ecological process on coral reefs. Ecosystems 12:1316-1328

Hoey AS, Brandl SJ, Bellwood DR (2013) Diet and cross-shelf distribution of rabbitfishes (f. Siganidae) on the northern Great Barrier Reef: implications for ecosystem function. Coral Reefs 32:973-984

Huang H (2018) Coral reef atlas of Xisha Islands. Science Press, Beijing

Kopp D, Bouchon-Navaro Y, Cordonnier S, Haouisee A, Louis M, Bouchon C (2010) Evaluation of algal regulation by herbivorous fishes on Caribbean coral reefs. Helgoland Mar Res 64:181-190

Kumar S, Stecher G, Li M, Knyaz C, Tamura K (2018) MEGA X: molecular evolutionary genetics analysis across computing platforms. Mol Biol Evol 35:1547-1549

Kume G, Kobari T, Hirai J, Kuroda H, Takeda T, Ichinomiya M, Komorita T, Aita-Noguchi M, Hyodo F (2021) Diet niche segregation of co-occurring larval stages of mesopelagic and commercially important fishes in the Osumi Strait assessed through morphological, DNA metabarcoding, and stable isotope analyses. Mar Biol 168:6

Lefevre CD, Bellwood DR (2011) Temporal variation in coral reef ecosystem processes: herbivory of macroalgae by fishes. Mar Ecol Prog Ser 422:239-251

Leray M, Meyer CP, Mills SC (2015) Metabarcoding dietary analysis of coral dwelling predatory fish demonstrates the minor contribution of coral mutualists to their highly partitioned, generalist diet. PeerJ 3:1047. 
Li YC, Chen SQ, Zheng XQ, Cai ZF, Wu ZJ, Wang DR, Lan JX (2018) Analysis of the change of hermatypic corals in Yongxing Island and Qilianyu Island in nearly a decade. Haiyang Xuebao 40:97-109 (in Chinese with English abstract)

Li YC, Wu ZJ, Chen SQ, Cai ZF, Lan JX, Tong YH, Yao HJ (2017) Discussion of the diversity of the coral reef fish in the shallow reefs along the Yongxing and Qilianyu island. Marine Environmental Science 36:509-516 (in Chinese with English abstract)

Liu Y, Wu P, Li CH, Xiao YY, Wang T, Lin L (2021) The bacterial composition associated with Atriolum robustum, a common ascidian from Xisha coral reef, China. Symbiosis 83:153-161

Magoc T, Salzberg SL (2011) FLASH: fast length adjustment of short reads to improve genome assemblies. Bioinformatics 27:2957-2963

Mantyka CS, Bellwood DR (2007) Macroalgal grazing selectivity among herbivorous coral reef fishes. Mar Ecol Prog Ser 352:177-185

Michael PJ, Hyndes GA, Vanderklift MA, Verges A (2013) Identity and behaviour of herbivorous fish influence large-scale spatial patterns of macroalgal herbivory in a coral reef. Mar Ecol Prog Ser 482:227240

Moberg F, Folke C (1999) Ecological goods and services of coral reef ecosystems. Ecol Econ 29:215-233

Neilson BJ, Wall CB, Mancini FT, Gewecke CA (2018) Herbivore biocontrol and manual removal successfully reduce invasive macroalgae on coral reefs. PeerJ 6:5332

Pruesse E, Quast C, Knittel K, Fuchs BM, Ludwig WG, Peplies J, Glockner FO (2007) SILVA: a comprehensive online resource for quality checked and aligned ribosomal RNA sequence data compatible with ARB. Nucleic Acids Res 35:7188-7196

Puk LD, Ferse SCA, Wild C (2016) Patterns and trends in coral reef macroalgae browsing: a review of browsing herbivorous fishes of the Indo-Pacific. Rev Fish Biol Fisher 26:53-70

Rodriguez-Barreras R, Godoy-Vitorino F, Praebel K, Wangensteen OS (2020) DNA metabarcoding unveils niche overlapping and competition among Caribbean sea urchins. Reg Stud Mar Sci 40:101537

Russ GR, Questel SL, Rizzari JR, Alcala AC (2015) The parrotfish-coral relationship: refuting the ubiquity of a prevailing paradigm. Mar Biol 162:2029-2045

Shen JW, Wang Y, Zhao N, Yang HQ, Fu FX, Jin YB (2017) Carbonate sedimentary characteristics of the beach rocks around Qilian Islets and Cays, Xisha Islands: Implication for coral reef development and decline. Palaeogeogr Palaeocl 474:264-278 
Streit R, Hoey A, Bellwood D (2015) Feeding characteristics reveal functional distinctions among browsing herbivorous fishes on coral reefs. Coral Reefs 34:1037-1047

Sura SA, Molina NE, Blumstein DT, Fong P (2021) Selective consumption of macroalgal species by herbivorous fishes suggests reduced functional complementarity on a fringing reef in Moorea, French Polynesia. J Exp Mar Biol Ecol 536:151508

Titlyanov AE, Titlyanova VT, Li X, Huang H (2016) Coral reef marine plants of Hainan island. Academic Press, Cambridge

Vermeij MJA, Smith JE, Smith CM, Thurber RV, Sandin SA (2009) Survival and settlement success of coral planulae: independent and synergistic effects of macroalgae and microbes. Oecologia 159:325-336

Vieira C (2020) Lobophora-coral interactions and phase shifts: summary of current knowledge and future directions. Aquat Ecol 54:1-20

Wang Q, Garrity GM, Tiedje JM, and Cole JR (2007) Naive Bayesian classifier for rapid assignment of rRNA sequences into the new bacterial taxonomy. Appl Environ Microb 73:5261-5267

Walker P, Wood E (2005) The coral reef. Facts on File, New York

Wilkinson C (2008) Status of coral reefs of the world: 2008. Global coral reef monitoring network and reef and rainforest research centre, Townsville

Zhao MX, Yu KF, Shi Q, Yang HQ, Riegl B, Zhang QM, Yan HQ, Chen TR, Liu GH, Lin ZY (2016) The coral communities of Yongle atoll: status, threats and conservation significance for coral reefs in South China Sea. Mar Freshwater Res 67:1888-1896

Zhao MX, Yu KF, Shi Q, Yang HQ, Riegl B, Zhang QM, Yan HQ, Chen TR, Liu GH, Lin ZY (2017) Comparison of coral diversity between big and small atolls: a case study of Yongle atoll and Lingyang reef, Xisha Islands, central of South China Sea. Biodivers Conserv 26:1143-1159

Zhao N, Shen DS, Shen JW (2019) Formation mechanism of beach rocks and its controlling factors in coral reef area, Qilian Islets and Cays, Xisha Islands, China. J Earth Sci-China 30:728-738

\section{Tables}

Table 1 Basic information on the coral reef fish species sampled in this study 


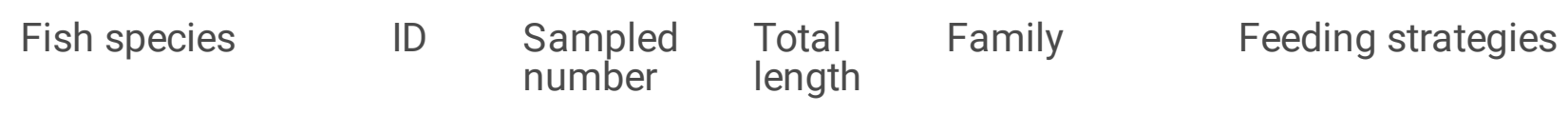

$(\mathrm{mm})$

\begin{tabular}{|c|c|c|c|c|c|}
\hline C. carolinus & $\mathrm{CC}$ & 3 & $227 \pm 8$ & Scaridae & Herbivorous (Sura et al. 2021) \\
\hline K. cinerascens & $\mathrm{KC}$ & 4 & $291 \pm 71$ & Kyphosidae & Herbivorous (Choat et al. 2004) \\
\hline K. vaigiensis & $\mathrm{KV}$ & 3 & $224 \pm 9$ & Kyphosidae & $\begin{array}{l}\text { Herbivorous (Choat et al. 2004; } \\
\text { Streit et al. 2015) }\end{array}$ \\
\hline N. brevirostris & NB & 3 & $202 \pm 15$ & Acanthuridae & Herbivorous (Choat et al. 2004) \\
\hline N. unicornis & NU & 3 & $236 \pm 20$ & Acanthuridae & $\begin{array}{l}\text { Herbivorous (Choat et } \\
\text { al. 2004; Streit et al. 2015; Sura } \\
\text { et al. 2021) }\end{array}$ \\
\hline S. argenteus & SA & 5 & $248 \pm 20$ & Siganidae & Herbivorous (Hoey et al. 2013) \\
\hline S. puellus & $\mathrm{SPe}$ & 3 & $221 \pm 43$ & Siganidae & $\begin{array}{l}\text { Herbivorous (Bennett and } \\
\text { Bellwood, 2011; Hoey et } \\
\text { al. 2013) }\end{array}$ \\
\hline
\end{tabular}

$\begin{array}{lllll}\text { S. punctatissimus SPn } 3 & 298 \pm 18 \text { Siganidae } & \begin{array}{l}\text { Herbivorous (Cvitanovic and } \\ \text { Bellwood, 2009) }\end{array}\end{array}$

Table 2 Macrophyte fragments observed by microscopic examination in the intestinal contents of fishes from the Xisha coral reefs 


\begin{tabular}{|lll|}
\hline Fish species & $\begin{array}{l}\text { Number of observed } \\
\text { macrophytes species }\end{array}$ & $\begin{array}{l}\text { Photographs of macrophytes fragments in fish } \\
\text { intestine }\end{array}$ \\
\hline C. carolinus & 1 & \\
(CC) & 2 & \\
K. cinerascens & 2 & \\
(KC) & 2 & \\
K. vaigiensis & 2 \\
(KV) & &
\end{tabular}




\begin{tabular}{|lll|l|l|}
\hline Fish species & $\begin{array}{l}\text { Number of observed } \\
\text { macrophytes species }\end{array}$ & $\begin{array}{l}\text { Photographs of macrophytes fragments in fish } \\
\text { intestine }\end{array}$ \\
\hline $\begin{array}{l}\text { S. argenteus } \\
\text { (SA) }\end{array}$ & & & \\
\end{tabular}

Table 3 Taxonomic assignment of the dominant OTUs affiliated to the phyla Chlorophyta, Ochrophyta and Rhodophyta, found in fish intestines using BLAST methodologies. 


\begin{tabular}{|c|c|c|c|c|}
\hline Phylum & OTUs & Fish species & $\begin{array}{l}\text { Closely related sequence } \\
\text { (Accession number) }\end{array}$ & Similarity \\
\hline \multirow[t]{4}{*}{ Chlorophyta } & Otu000030 & KV & $\begin{array}{l}\text { Dictyosphaeria } \\
\text { cavernosa (AM498756) }\end{array}$ & $99.1 \%$ \\
\hline & Otu000055 & SA $\square \mathrm{KC}$ & Ulvella leptochaete (LM653280) & $97.4 \%$ \\
\hline & Otu000067 & KC & Cladophora socialis (AM498751) & $99.1 \%$ \\
\hline & Otu000102 & $\mathrm{NB} \square S A$ & $\begin{array}{l}\text { Cladophora } \\
\text { vagabunda (LT607383) }\end{array}$ & $100 \%$ \\
\hline \multirow[t]{3}{*}{ Ochrophyta } & Otu000009 & $\begin{array}{l}\mathrm{CC} \square \mathrm{KV} \square S P n \square N B \square N U \square \\
\text { Spe } \square \mathrm{KC}\end{array}$ & Lobophora variegate (AB096086) & $99.2 \%$ \\
\hline & Otu000014 & SA $\square C C$ & Dictyota linearis (AB087108) & $99.2 \%$ \\
\hline & Otu000078 & NB & Sphacelaria rigidula (LM653281) & $97.5 \%$ \\
\hline \multirow[t]{14}{*}{ Rhodophyta } & Otu000056 & SA & Spyridia filamentosa (EU718707) & $99.4 \%$ \\
\hline & Otu000077 & SA $\square S P n$ & $\begin{array}{l}\text { Centroceras hyalacanthum } \\
\text { (DQ374387) }\end{array}$ & $90.5 \%$ \\
\hline & Otu000094 & $\mathrm{KC} \square \mathrm{SPn}$ & Ceramium sinicola (AY155519) & $88.4 \%$ \\
\hline & Otu000189 & NB & $\begin{array}{l}\text { Taenioma } \\
\text { perpusillum (MF093957) }\end{array}$ & $86.7 \%$ \\
\hline & Otu000200 & KV & $\begin{array}{l}\text { Peyssonnelia } \\
\text { rumoiana (AB231315) }\end{array}$ & $98.5 \%$ \\
\hline & Otu000260 & KV & $\begin{array}{l}\text { Peyssonnelia } \\
\text { armorica (AB231316) }\end{array}$ & $96.8 \%$ \\
\hline & Otu000278 & SpelKV & $\begin{array}{l}\text { Centroceras micracanthum } \\
\text { (DQ374386) }\end{array}$ & $96.8 \%$ \\
\hline & Otu000309 & NU & $\begin{array}{l}\text { Chondrophycus cf. } \\
\text { undulates (GU223780) }\end{array}$ & $97.1 \%$ \\
\hline & Otu000443 & Spe & Gibsmithia dotyi (AF317108) & $99.1 \%$ \\
\hline & Otu000512 & Spe & $\begin{array}{l}\text { Erythrophyllum } \\
\text { delesserioides (AF317105) }\end{array}$ & $97.7 \%$ \\
\hline & Otu000535 & $\mathrm{CC}$ & $\begin{array}{l}\text { Peyssonnelia } \\
\text { rosenvingei (AB231317) }\end{array}$ & $97.7 \%$ \\
\hline & Otu000554 & $\mathrm{CC}$ & $\begin{array}{l}\text { Pneophyllum conicum } \\
\text { (MF611677) }\end{array}$ & $100 \%$ \\
\hline & Otu000675 & SPn & $\begin{array}{l}\text { Neosiphonia sp. NDR51A } \\
\text { (AB219905) }\end{array}$ & $98.5 \%$ \\
\hline & Otu000874 & NU & Ceramium sinicola (AY155519) & $87.8 \%$ \\
\hline
\end{tabular}




\section{Figures}

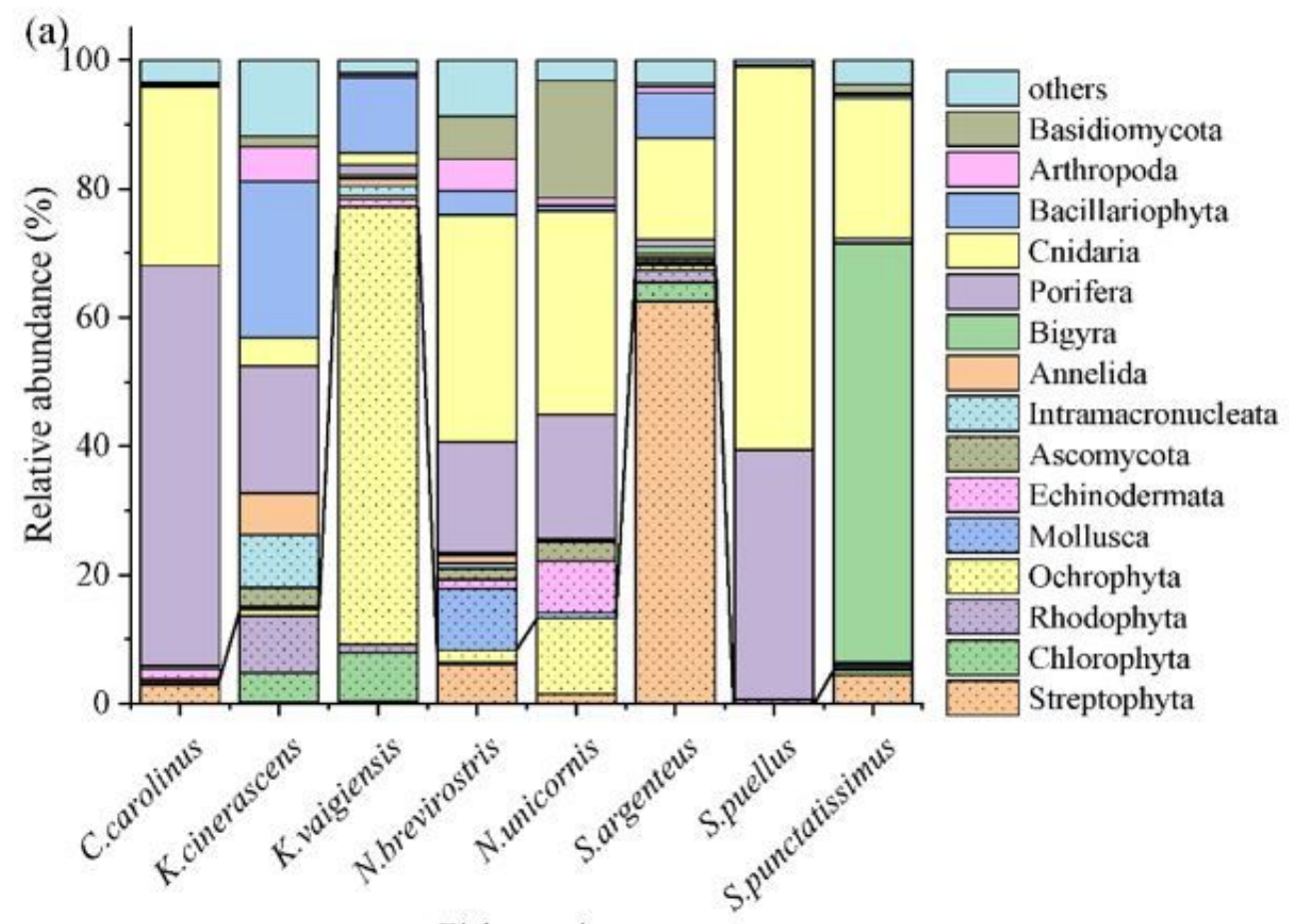

Fish species

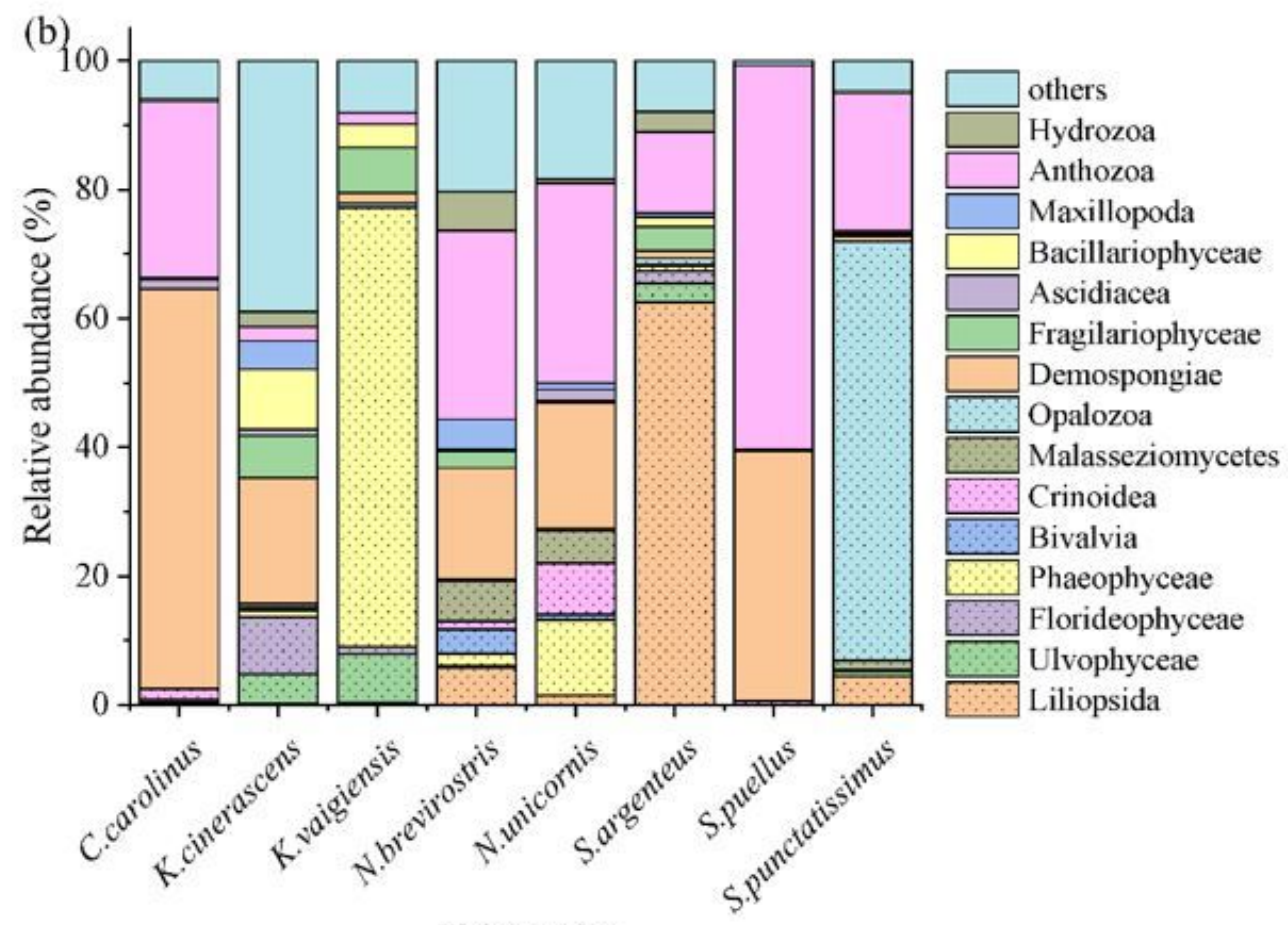

Fish species

\section{Figure 1}

Relative abundances of eukaryote sequences found in fish intestines, determined with 18S rRNA highthroughput sequencing. a phylum level. Polylines show the sum of the relative abundance of the phyla Streptophyta, Chlorophyta, Ochrophyta and Rhodophyta. b class level. 


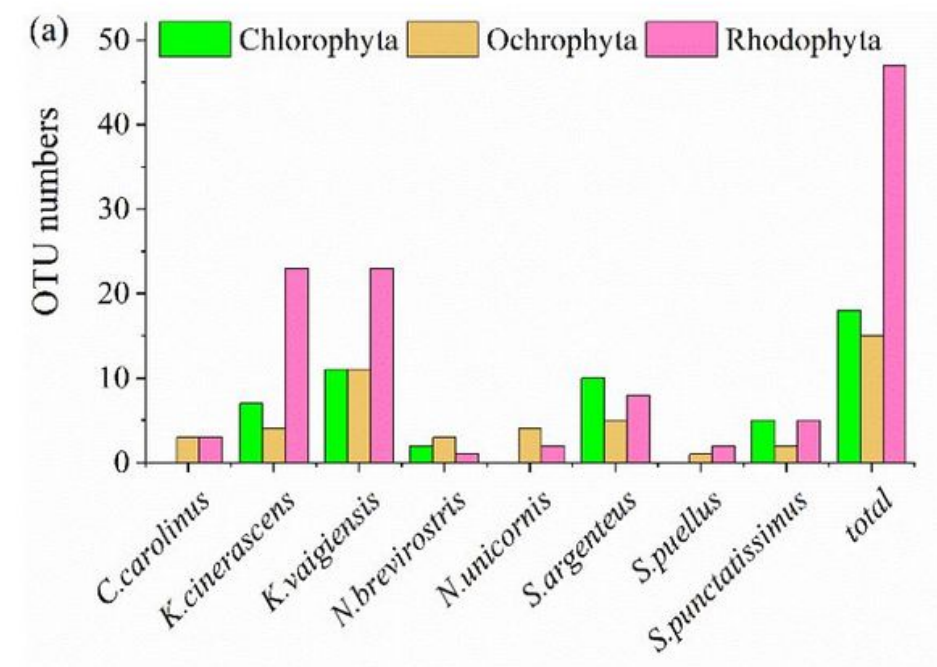

Fish species

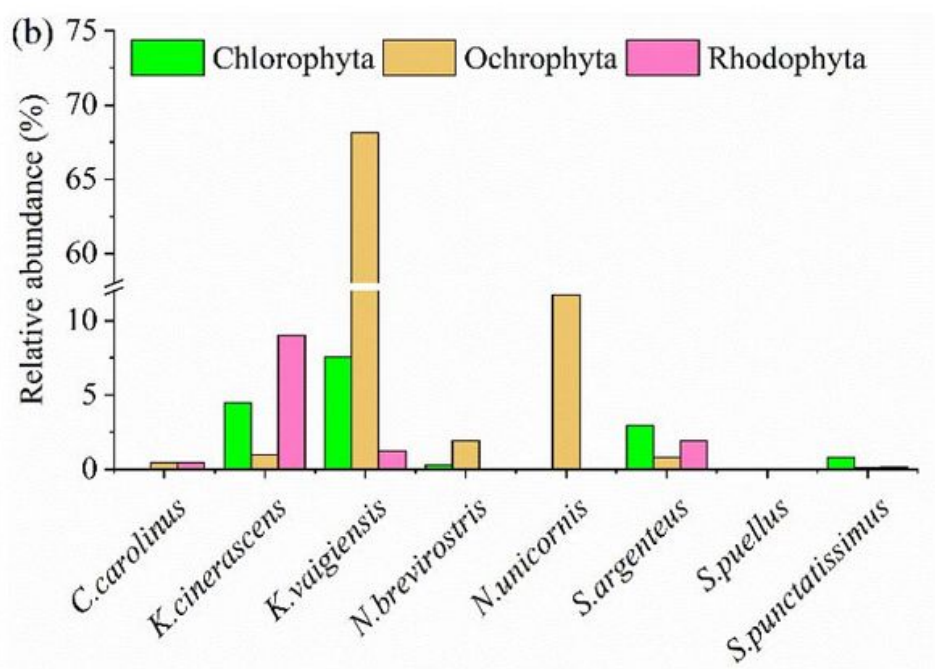

Fish species

\section{Figure 2}

Eukaryote sequences belonging to the phyla Chlorophyta, Ochrophyta and Rhodophyta obtained from intestinal contents of eight coral reef fish species. a OTU numbers of taxonomic groups. b Relative abundance of taxonomic groups. 


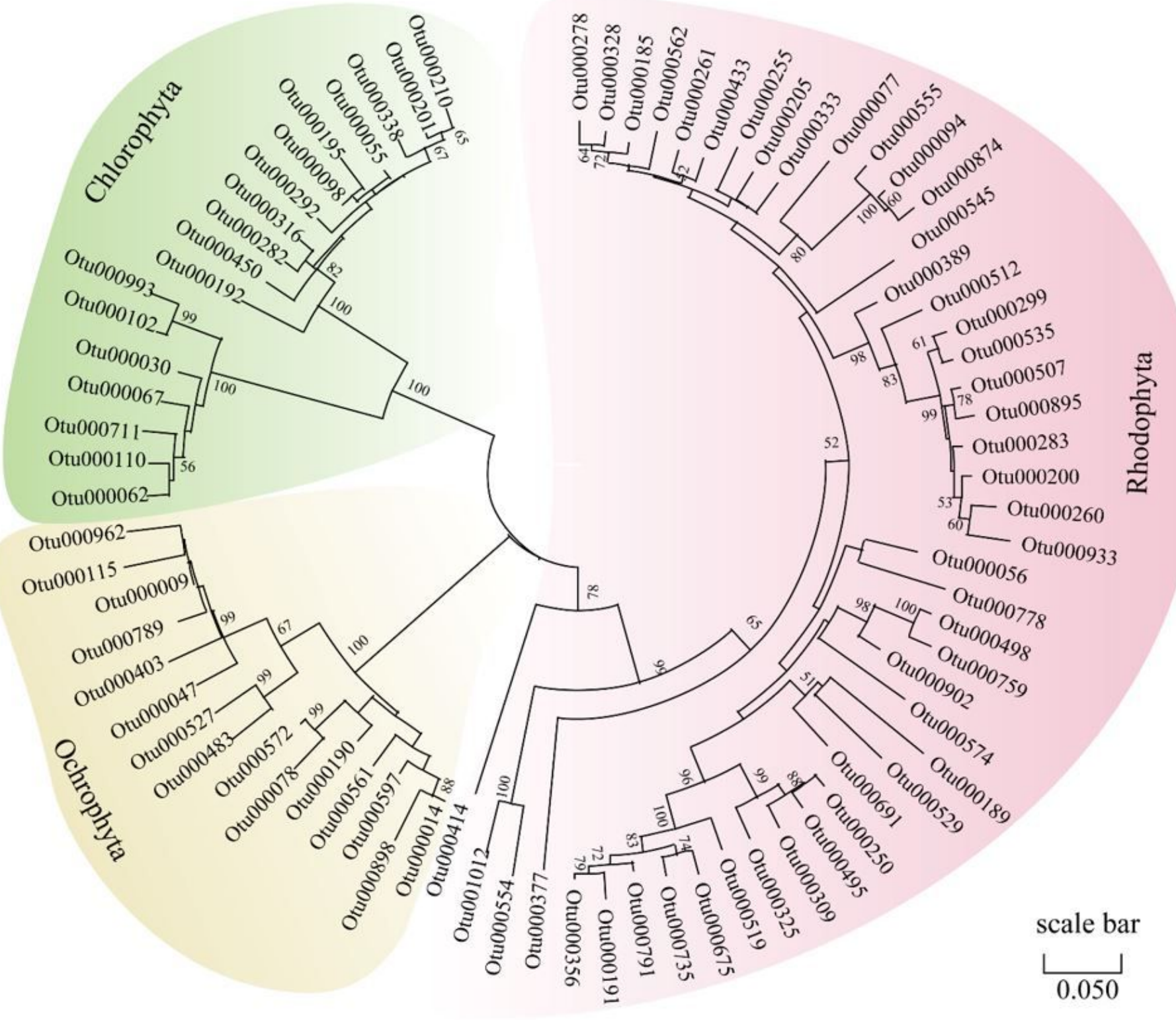

Figure 3

Neighbor-joining tree of $18 \mathrm{~S}$ rRNA sequences affiliated to the phyla Chlorophyta, Ochrophyta and Rhodophyta obtained from the intestinal contents of eight coral reef fish species. The scale bar represents $5 \%$ estimated sequence divergence. 
(a)

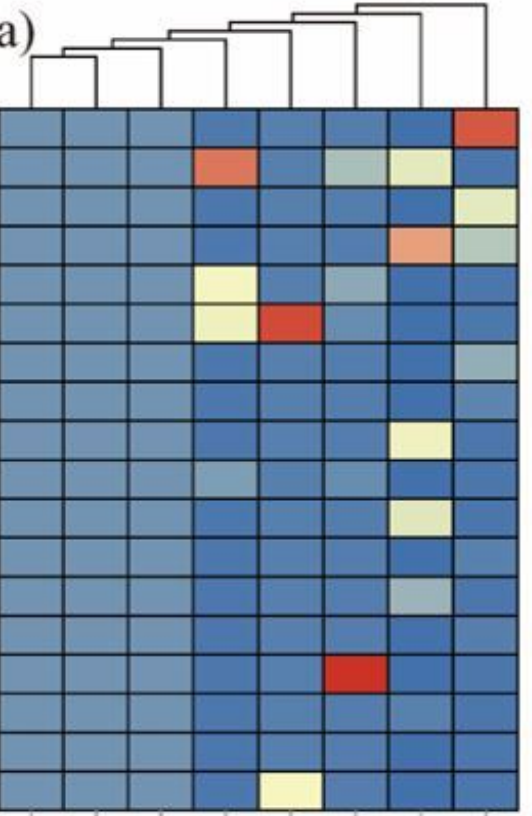

C丩⿻上丨子东

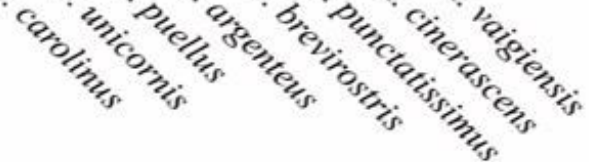

(b)

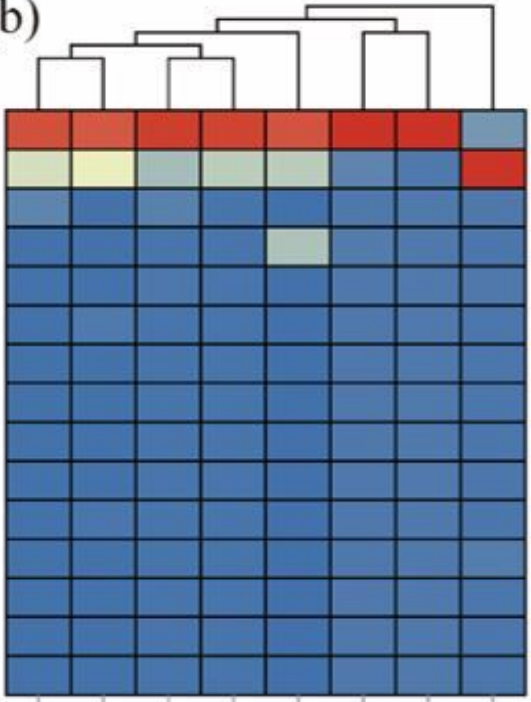

Otu000009

Otu000014

Otu000047

Otu000078

Otu000115

Otu000190

Otu000403

Otu000483

Otu000527

Otu000561

Otu000572

Otu000597

Otu000789

Otu000898

Otu000962

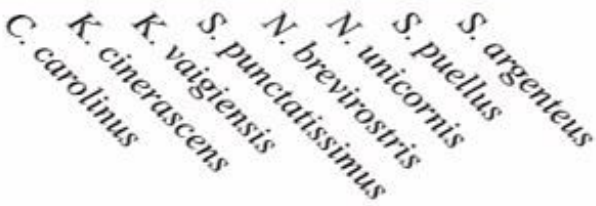

(c)

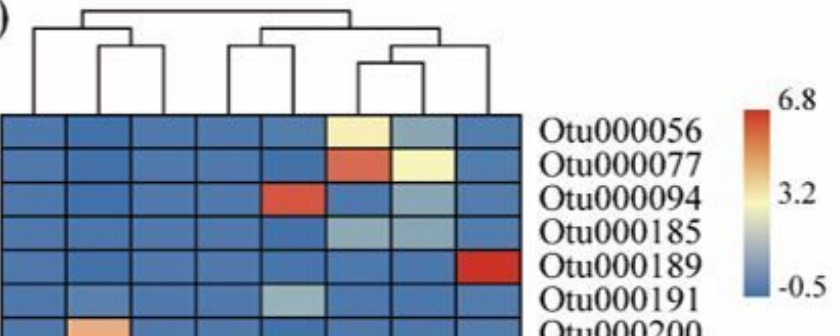

Otu000200

Otu000205

Otu000250

Otu000255

Otu000260

Otu000261

Otu000278

Otu000283

Otu000299

Otu000309

Otu000325

Otu000328

Otu000333

Otu000356

Otu000377

Otu000389

Otu000414

Otu000433

Otu000495

Otu000498

Otu000507

Otu000512

Otu000519

Otu000529

Otu000535

Otu000545

Otu000554

Otu000555

Otu000562

Otu000574

Otu000675

Otu000691

Otu000735

Otu000759

Otu000778

Otu000791

Otu000874

Otu000895

Otu000902

Otu000933

Otu001012

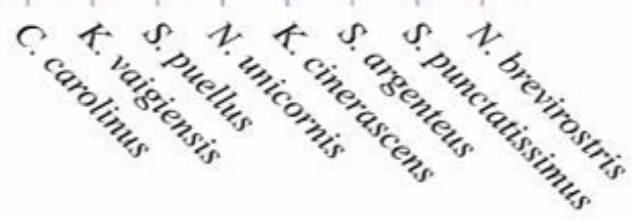

\section{Figure 4}

Heat map of the relative abundance of $18 \mathrm{~S}$ rRNA sequences affiliated with different phyla found in the intestinal contents of eight coral reef fish species. a Chlorophyta, b Ochrophyta, c Rhodophyta. 


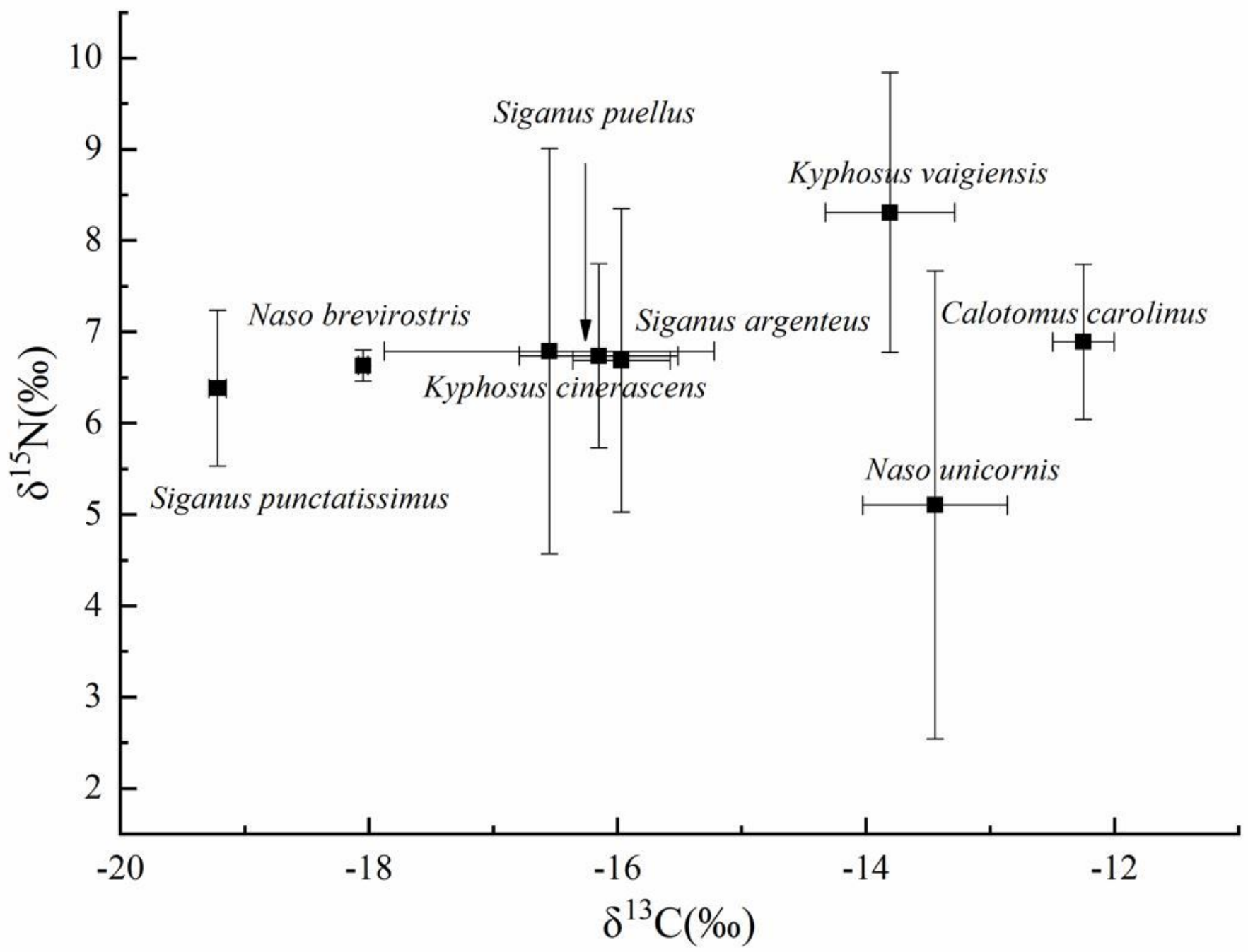

Figure 5

$\delta 13 \mathrm{C}$ and $\delta 15 \mathrm{~N}$ isotope values of eight coral reef fish species from the Xisha Islands. Data points are averages with standard error bars. 